DOI: $10.20472 / E S .2020 .9 .2 .004$

\title{
INSTITUTIONS AND FOREIGN DIRECT INVESTMENT: A PANEL VAR APPROACH
}

\section{ICHRAF OUECHTATI}

\begin{abstract}
:
This paper employs panel vector autoregression model (PVAR) for a panel of 90 developing countries over 17 years (2000-2016) to empirically examine the relationship between institutional shocks and foreign direct investment (FDI). The study finds that institutional shocks have a negative impacts on FDI. Generally, the effect begins to mitigate from the fourth year. This result could be explained mainly by the instability of institutional variables « Regulation of credit, labor and business » and « government size » in the case of FDI inflows and outflows. The effect is higher in the case of FDI inflows. This suggests that investors already settled in developing countries are less sensitive to institutional shocks.

Also, results reveal that the negative impact of institutional shocks on net FDI is explained by the instability of legal structure and property rights and access to sound money.
\end{abstract}

\section{Keywords:}

Institutions, Foreign direct investment, Panel VAR

JEL Classification: C14, C33, 011

\section{Authors:}

ICHRAF OUECHTATI, Faculty of Law, Economics and Management Sciences of Jendouba, Tunisia, Email: ouechtati.ichraf@yahoo.fr

\section{Citation:}

ICHRAF OUECHTATI (2020). Institutions and foreign direct investment: A Panel VAR approach. International Journal of Economic Sciences, Vol. IX(2), pp. 55-70., 10.20472/ES.2020.9.2.004 


\section{Introduction}

The study of the determinants of FDI attractiveness' level of a country interests more and more researchers, and this is because of their belief in the major role of FDI in the reinforcement of economic growth.

The work of Dunning J.H (1998) has attracted the attention of several scholars. His approach, known as the OLI paradigm (ownership advantage, localisation advantage, international advantage), distinguishes some advantages resulting from the decision of establishment in a country which are summarized mainly in the exclusive right of the intellectual property of its products, the access to natural resources and reduction of transaction and production costs. Several other studies have focused on economic factors (market size, inflation, exchange rate, etc.) as the main determinants of FDI attractiveness (Azam, M., \& Khattak, N. (2009), Grosse, R., \& Trevino, L. J (1996), Gomes, N and Veiga, F. J (2013), Sanchez-Mart'ın Miguel Eduardo et al. (2014), Hsu and Tiao (2015)).

From the 1990s and following the work of D. North, the concept of "institutions" begins to paid a particular attention in explaining its importance in attracting FDI (Gastanaga, Nugent and Pahamova, 1998, Loree and Guisinger, 1995, Sethi, Guisinger, Phelan and Berg, 2003).

Preparing a healthy institutional infrastructure is crucial for countries to attract more FDI. An appropriate institutional environment must ensure a better political stability, a successful democracy, a salient transparency and good governance.

From a theoretical point of view, it is reasonable to assume that a good institutional environment admittedly enhances FDI attracting and the relationship becomes positive between them. Nevertheless, empirical researches find positive or negative effects which can be significant or insignificant. For example, some scholars have shown that a bad governance does not attract FDI flows (Bellos et al, 2012). While Amal, M et al. (2010) find, by examining the effect of macroeconomic and institutional factors on FDI in Latin America, that government efficiency has a significant negative effect on FDI inflows.

Overall, the literature on institutions and FDI link is very rich. Aside from being ambiguous, reviewing the existing literature, we found that scholars have dealt with the issue from different angles. Some have focused on institutional stability and its effect on FDI flows (N. Mahmood et al (2018), others on the dynamic relationship between them (Kurul, 2017) and also on low institutional quality and the volatility of FDI inflows (Buchanan (2012)). However, and to the best of our knowledge assessing the effect of institutional innovations on FDI by using panel VAR approach has not been examined in the literature. Some countries choose to reform and innovate their institutions without estimating in advance the real effects on investment and economic growth and without studying what type of institutions they should innovate.

The main objective of this research is to explore the impact of institutional shocks on FDI (inflows, outflows and net) for a panel of 90 developing countries over the periode 2000- 2016. For this, we use the panel vector autoregression (PVAR) approach in the manner of Abrigo and Love (2015), and analyze orthogonalized impulse response functions and variance decompositions.

The contributions of this study to the existing literature are threefold: first, we analyze the effect of institutional shocks on three FDI variables (FDI inflows, FDI outflows and net FDI) and this to show what type of FDI can be affected more than others through institutional innovations. Second, we contribute to the literature by using various institutional measures to identify which of the institutional aspects affects FDI in developing countries. Third, we use in our empirical 
essay not only different dimensions of institutional quality but also a composite institutional indicator to estimate the effect of an overall institutional shock on FDI.

The remainder of the paper proceeds as follows: section 2 presents the literature review, Section 3 describes data and presents the methodology. Section 4 presents and analyses empirical results. Section 5 concludes.

\section{Literature review}

The theoretical basis explaining the relationship between FDI and institutions considers that companies choose to settle in one host country over another, depending on the associated costs.

When the territory and the workforce offer abundant supplies, their cost is generally low. A country with abundant or productive resources will not only develop its industrial activity by exploiting its own resources but will also attract foreign companies (the traditional theory of international trade).

This cost minimization objective was also supported by the product life cycle theory (Vernon (1966)). According to this, once produced in developed countries, the goods are ultimately manufactured at low cost in developing countries and then exported to their domestic countries. Otherwise, when the product becomes standard and mature, labor costs become very important in the production process, it is at this point that firms outsource in search of low production costs. From the 1970s, some economists, in particular, Buckley and Casson (1976), hymer (1976) and Hennart (1982) proposed the application of the theory of internationalization in order to explain the growth of multinational firms, based on the theory of transaction costs. The choice between serving and investing in an external market through export or franchising depends on certain costs, such as opportunity costs, installation costs, maintenance costs, etc.

The theory of internationalization was launched by Coase in 1937 in a national context and Hymer in 1976 in an international context. The latter considers that the imperfections of the product and factor markets are the main determinants of direct investment.

In his thesis, he identifies two key determinants of FDI. One is the removal of competition. The other is the advantages that certain companies have in a particular activity (Hymer, 1976). From this theoretical background, we can see that generally the costs associated with setting up in a host country represent a major determinant of FDI.

Studies looking at different institutional dimensions have shown that government, institutions and policies can increase or decrease these costs and thus influence the attractiveness of FDI (Root and Ahmed, 1979). Good governance, better control of corruption and a favorable regulatory environment can reduce costs and attract FDI flows (Golberman and Shapiro (2002), Bailey (2017)). In this context, Kurul et al. (2017) empirically studied this relationship in 113 developing countries. They find that certain institutional factors are much more important than others in attracting FDI flows.

In the same vein, several other studies have also shown that low levels of corruption, greater political stability and government efficiency decreases costs and have positive effects on FDI (Gani, 2007, Gani and Al-Abri, 2013). 
In contrast, some studies have shown that the high level of corruption, low political stability, and a weak legal system do not affect the costs and location decision of US multinational corporations (Wheeler et al, 1992).

In general, empirical research conclude that attracting FDI requires good governance and a strong institutional structure. Among institutional factors that receive the most significant scholarly attention in boosting or detering FDI flows, we can cite corruption and political factors. Gastanaga et al. (1998) find that low levels of corruption and good contract performance lead to increased FDI flows. Similarly, Wei (2000a) concludes in their research that corruption has a negative effect on the multinationals' preferences for FDI location. It increases transaction costs and uncertainty. Its negative impact on the inwards FDI was confirmed by several scholars (Woo, 2010, Samimi et al (2011), Brada et al (2012), Alemu (2012), Quazi (2014)). However, the effect of corruption on FDI remains uncertain since Cuervo- Cazurra (2006) examines in its paper this impact. Among their key findings, he notes that corruption leads to relatively higher FDI when it comes to investment from a country with high corruption. This suggests that investors working at home in a corrupt environment will indeed seek countries where corruption is widespread.

Political factors are crucial determinant of FDI (Stevens (1969), Root and Ahmed (1979), Levis (1979)). Regarding political stability and according to some scholars, countries with stable institutions are more likely to attract FDI than others (Globerman and Shapiro, 2003). Studying the relationship between trade and investment, Buthe and Milner (2008) find that political factors that influence these flows are not well understood and to attract more FDI, it is necessary to follow the international commitments provided by international trade agreements that are credible and reliable. Woodward and Rolfe (1993) confirming such a positive relationship between FDI and political stability by testing a set of macroeconomic variables in the Caribbean Basin.

Democratic institutions, defined mainly as political freedom and civil liberties, have also been the subject of several studies. Jensen (2003) finds that democratic governments are more stable and more credible and attract up to $70 \%$ more FDI compared to authoritarian states. Li and Resnick (2003) confirm this favorable effect of democratic institutions on FDI only when the dispersion of power in a democracy is high because it reduces the risk for foreign investors. The same is true for Ahlquist (2006), who states that democratic countries attract far more FDI than authoritarian countries because democratic regimes tend to reduce the political risks of nationalization and expropriation and to increase the credibility of the host country with foreign investors.

Several other studies have shown that an increase in FDI is possible if political freedoms and civil liberties are more protected (Harms and Ursprung, 2002, Globerman and shapiro, 2003, Kolstad and Villanger, 2008).

Control of corruption, government effectiveness and accountability positively and significantly affect FDI flows. Asiedu (2006) shows that ineffective institutions such as political instability, corruption and the lack of the rule of law inhibit FDI inflows. Aizenman and Spiegel (2006) focus on the implications of institutions efficiency on the pattern of FDI. They find that institutional efficiency is positively associated with the ratio of FDI flows to gross fixed capital formation and to private investment (associated with the ratio of subsequent foreign direct investment flows to both gross fixed capital formation and to private investment). 
Other studies analyzing this same question have chosen to explore the impact of a composite institutional indicator on the attraction of FDI. Globerman and shapiro (2002) and Buchanan et al (2012) studied the effect of a composite indicator combining corruption control, the rule of law and political stability and concluded a positive impact on FDI flows. Buchanan et al (2012) specifies that if the institutional quality index positively affects FDI flows, it has a negative impact on the volatility of FDI flows.

Despite all these positive effects concluded in various works, the results remain mixed about this relationship. Indeed, some find no impact on FDI flows (Globerman and Shapiro, 2003, Trevino et al, 2008). The results remain ambiguous even for other institutional factors such as rule of law (Globerman \& Shapiro, 2003, Li \& Resnick, 2003), democracy (Jensen, 2003), tax rates (Gastanaga et al., 1998, Woodward \& Rolfe, 1993 ) and cultural distance (Grosse \& Trevino, 1996, Buckley, Clegg, \& Wang, 2007).

In general, there is a rich literature exploring the effect of institutional variables on FDI flows. However, the study of the impact of institutional innovations on FDI has received little attention.

\section{Data and methodology}

In this paper, we adopt a panel vector autoregression (PVAR) methodology, developed by Love and Zicchino (2006). The pvar model is appropriate because it does not make a priori restriction on the exogenous and endogenous variables. It allows to grasp the interdependencies both static and dynamic.

Also, PVAR models make it possible to process the links between the units without any a priori restriction, etc. In addition, they are particularly suitable for analyzing the transmission of shocks between units over time (Canova and Ciccarelli (2013)).

The PVAR model allows for unobserved individual heterogeneity in the levels of the variables by introducing fixed effects $\left(\mu_{i}\right)$

The following model is estimated :

$$
Y_{i t}=\mu_{i}+A(L) Y_{i t-1}+v_{i}+\theta_{t}+\varepsilon_{i t}
$$

Where $i=1,2, \ldots, N$ and $t=1, \ldots, T$

$Y_{i t}$ is FDI inflows, FDI outflows, Net FDI and institutional variables. $A$ is the lag operator. $v$ is an individual specific effect, $\theta$ is a fixed time effect and $\varepsilon$ is the error term.

The variables foreign direct investment, net inflows (\% GDP), foreign direct investment outflows (\% GDP) and net foreign direct investment are drawn from the World Bank's World Development 
Indicators and the institutional variables used in this paper are taken from Fraser Institute's Economic Freedom of the World : the summary index (sum) and its five institutions- related subcomponents, namely: size of government (sg), legal structure and security of property rights (Ispr), freedom to trade internationally (fti), regulation of credit, labor and business (reg) and sound money (sm).

The data are organized into a panel of 90 countries and 17 years (2000-2016).

\section{Results}

This section attempts to present the results of estimating the relationship between institutions and FDI. We empirically analyse the link between institutions and FDI inflows, institutions and FDI outflows and institutions and net FDI.

\subsection{Panel Data Unit Root Test}

Before performing PVAR analysis, we choose to test the stationarity of variables. The most frequently used tests are those of Levin-Lin-Chu (LLC) and Im-Persan-Shin (IPS). The application of LLC and IPS unit root tests shows that all of the statistical series are stationary in level (see Table 1).

Table 1. Panel Data Unit Root Test

\begin{tabular}{|l|l|l|}
\hline Statistic & Levin-Lin Chu -stat & IPS -stat \\
\hline Idenet & $-7.9296^{*}$ & $-2.4796^{*}$ \\
\hline Fdio & $-2.3932^{*}$ & $-4.5992^{*}$ \\
\hline Fdii & $-8.9699^{*}$ & $-2.4476^{*}$ \\
\hline Sum & $-9.2947^{*}$ & $-1.7808^{*}$ \\
\hline Sg & $-16.2129^{*}$ & $-1.9778^{*}$ \\
\hline Lspr & $-8.5520^{*}$ & $-2.0564^{*}$ \\
\hline Sm & $-4.0361^{*}$ & $-2.1466^{*}$ \\
\hline Fti & $-9.8129^{*}$ & $-1.9216^{*}$ \\
\hline Reg & $-11.489^{*}$ & $-2.0481^{*}$ \\
\hline
\end{tabular}

Source : author's estimates 


\subsection{Institutions and FDI inflows (fdii)}

Figure 1. Impulse Response Functions (Institutions and FDI inflows)

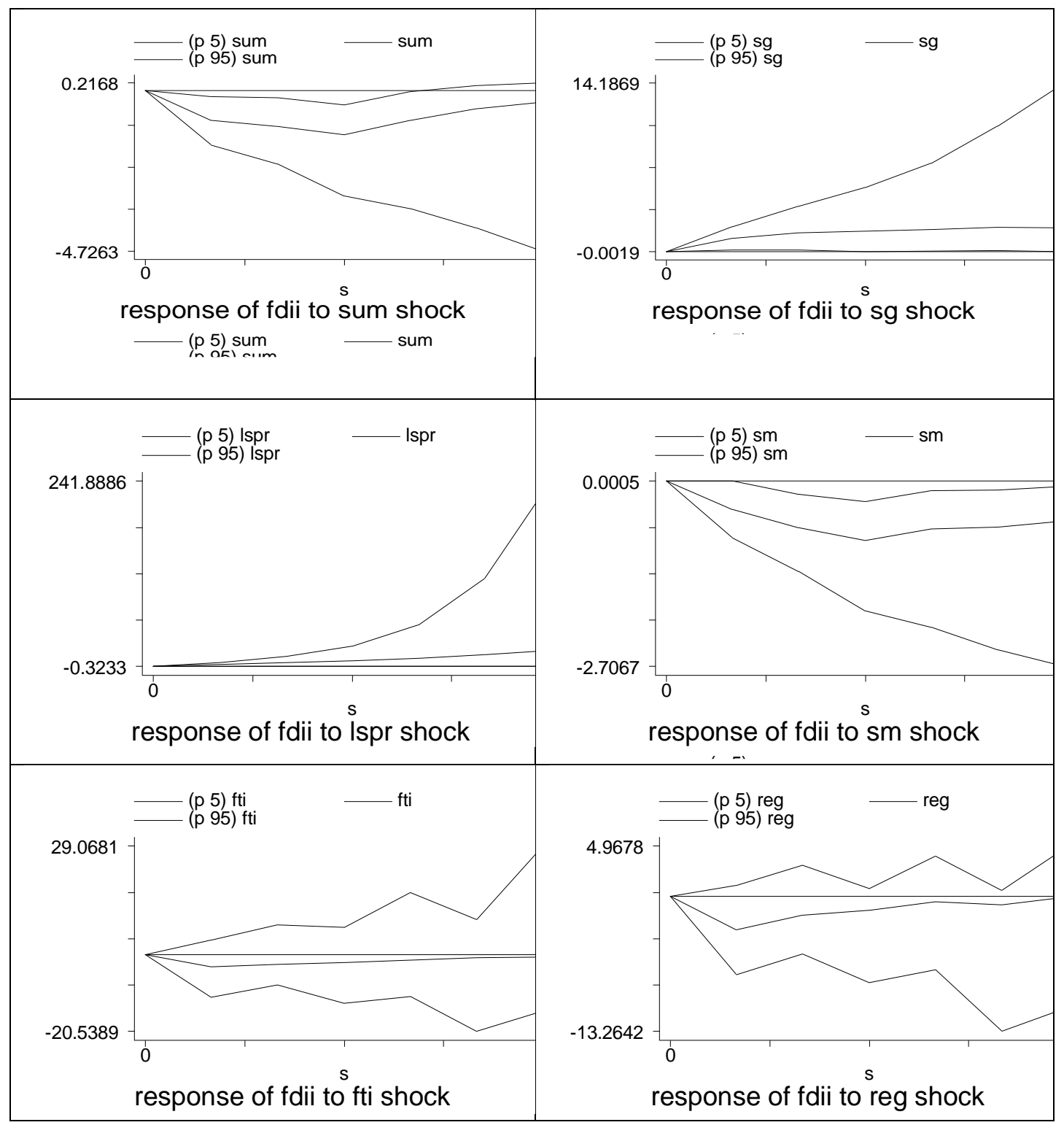

Source : author's estimates

Table 1. Variance decomposition of the PVAR model (Institutions and Inflows)

\begin{tabular}{|l|r|r|r|r|r|r|l|}
\hline & S & Fdii & Sg & Lspr & Sm & Fti & reg \\
\hline Fdii & 10 & 0,6895 & 0,1243 & 0,0624 & 0,0104 & 0,0315 & 0,0815 \\
\hline Sg & 10 & 0,0755 & 0,7137 & 0,0319 & 0,0025 & 0,0541 & 0,1220 \\
\hline Lspr & 10 & 0,1581 & 0,0994 & 0,5427 & 0,0124 & 0,0452 & 0,1418 \\
\hline Sm & 10 & 0,0768 & 0,0473 & 0,0144 & 0,6651 & 0,0466 & 0,1495 \\
\hline Fti & 10 & 0,0593 & 0,0273 & 0,0520 & 0,0102 & 0,8272 & 0,0237 \\
\hline Reg & 10 & 0,20006 & 0,2392 & 0,0521 & 0,0670 & 0,0237 & 0,4177 \\
\hline
\end{tabular}




\begin{tabular}{|l|r|r|r|r|r|r|r|}
\hline Fdii & 20 & 0,6868 & 0,1248 & 0,0622 & 0,0116 & 0,0314 & 0,0830 \\
\hline Sg & 20 & 0,0741 & 0,7050 & 0,0331 & 0,0030 & 0,0583 & 0,1262 \\
\hline Lspr & 20 & 0,1579 & 0,0993 & 0,5426 & 0,0128 & 0,0452 & 0,1419 \\
\hline Sm & 20 & 0,0763 & 0,0472 & 0,0174 & 0,6621 & 0,0471 & 0,1497 \\
\hline Fti & 20 & 0,0591 & 0,0271 & 0,0523 & 0,0129 & 0,8235 & 0,0249 \\
\hline Reg & 20 & 0,1980 & 0,2378 & 0,0521 & 0,0664 & 0,0255 & 0,4199 \\
\hline \multicolumn{7}{|r|}{ Source : author's estimates } \\
\hline
\end{tabular}

Figure 1, which describes the effect of an institutional shock on foreign investment inflows, shows a negative effect of institutional instability on foreign investment inflows. After the 2 nd year, the effect is accentuated. It is only from the 4th year that it starts to mitigate.

To better understand the origin of this impact, we studied the effect of a shock of each institutional sub-index separately. The overall observation of the different figures shows a negative stability of the paces showing a weak effect, except those of the access to the sound money and the quality of the regulation whose effect is not only negative but the magnitude is quite important compared to other sub-indices.

The variance decomposition table confirms the major role played by the "size of government" variable in the explanation of the other variables, which accounts for $12.43 \%$ in explaining the variance of inward FDI over 10 years. The table also shows that the variable "legal structure and security of property rights" accounts for $0.81 \%$ in the explanation of the variance of the inward FDI.

These results show that although developing countries are a supportive environment for investors in which they can, for example, benefit from low labor and transaction costs, but innovations and institutional shocks can hinder settlement decisions of investors in these countries in a first period of time. After, typically four years the effect is lightened and the dynamism of FDI inflows increases.

\subsection{Institutions and outflows (fdio)}

Figure 2. Impulse Response Functions (Institutions and outflows)

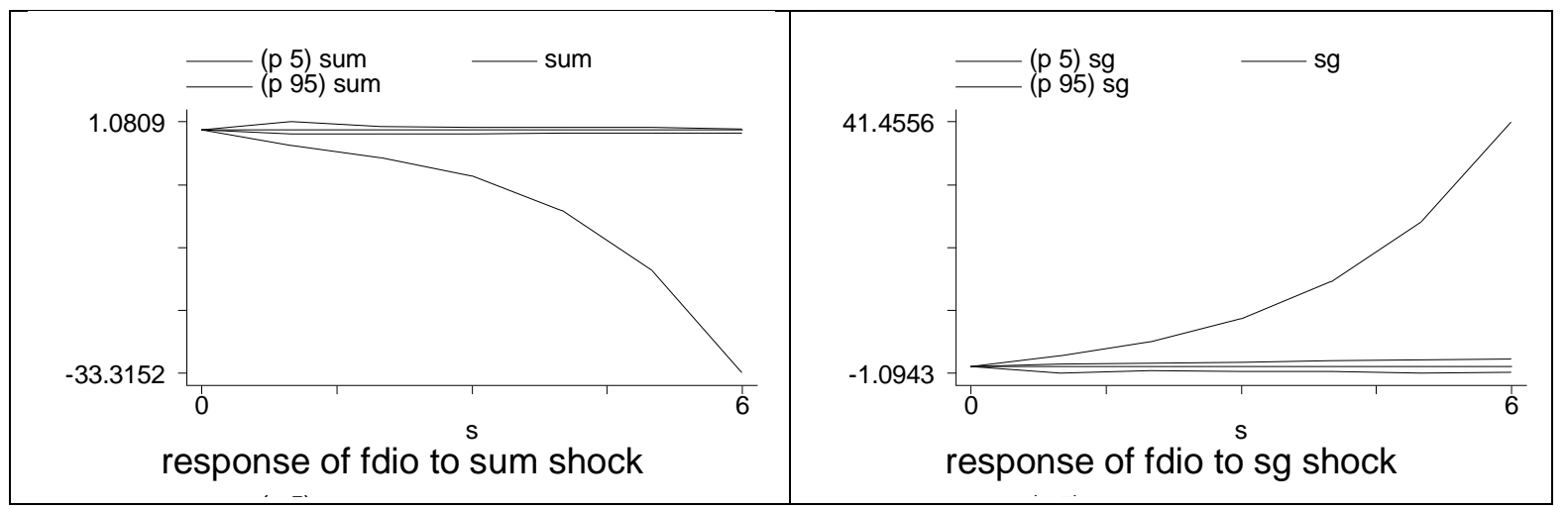




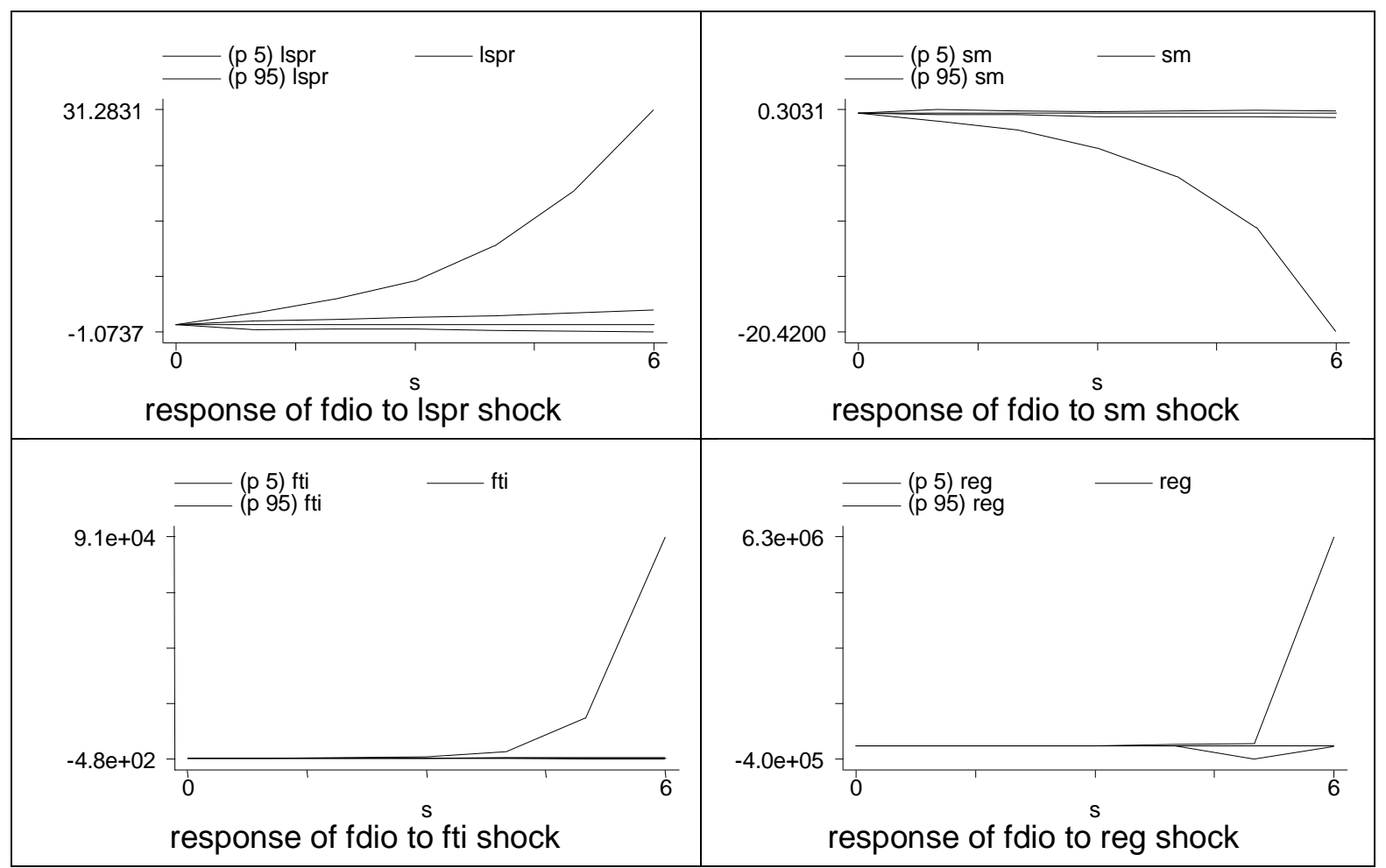

Source : author's estimates

Table 2. Variance decomposition of the pvar model (Institutions and outflows)

\begin{tabular}{|c|c|c|c|c|c|c|c|}
\hline & S & Fdio & $\mathrm{Sg}$ & Lspr & Sm & Fti & $\operatorname{Reg}$ \\
\hline Fdio & 10 & 0,7652 & 0,1224 & 0,0113 & 0,0078 & 0,0290 & 0,0641 \\
\hline $\mathrm{Sg}$ & 10 & 0,1445 & 0,5763 & 0,1473 & 0,0014 & 0,0491 & 0,0811 \\
\hline Lspr & 10 & 0,2095 & 0,4209 & 0,2399 & 0,0013 & 0,0471 & 0,0811 \\
\hline $\mathrm{Sm}$ & 10 & 0,1321 & 0,2534 & 0,0863 & 0,3569 & 0,0636 & 0,1074 \\
\hline Fti & 10 & 0,2012 & 0,3733 & 0,1337 & 0,0035 & 0,2421 & 0,0460 \\
\hline Reg & 10 & 0,1840 & 0,3701 & 0,1624 & 0,0341 & 0,0212 & 0,2280 \\
\hline Fdio & 20 & 0,7506 & 0,1221 & 0,0105 & 0,0074 & 0,0314 & 0,0778 \\
\hline $\mathrm{Sg}$ & 20 & 0,1440 & 0,5712 & 0,1464 & 0,0024 & 0,0518 & 0,0840 \\
\hline Lspr & 20 & 0,2105 & 0,4212 & 0,2381 & 0,0014 & 0,0471 & 0,0816 \\
\hline Sm & 20 & 0,1376 & 0,2517 & 0,0863 & 0,3520 & 0,0644 & 0,1078 \\
\hline Fti & 20 & 0,2049 & 0,3709 & 0,1329 & 0,0035 & 0,2407 & 0,0468 \\
\hline Reg & 20 & 0,1835 & 0,3707 & 0,1620 & 0,0343 & 0,0213 & 0,2279 \\
\hline
\end{tabular}

Source : author's estimates

Figure 2 shows the effects of institutional shocks on FDI outflows. Overall, an institutional shock has a very small negative effect on outward FDI. To better examine this impact, we use the variance decomposition. Table 2 shows that the two institutional variables that contribute most to the explanation of outward FDI are the size of government $(12.24 \%)$ and the regulation of credit, labor and business (0.64\%). over 10 years. This is confirmed over the period of 20 years.

This weak negative effect, which is lower than the case of the DFI inflows, can be interpreted by the low sensitivity of investors already settled in host countries to institutional changes and instabilities. 


\subsection{Institutions and net FDI}

Figure 3. Impulse Response Functions (Institutions and net fDI)

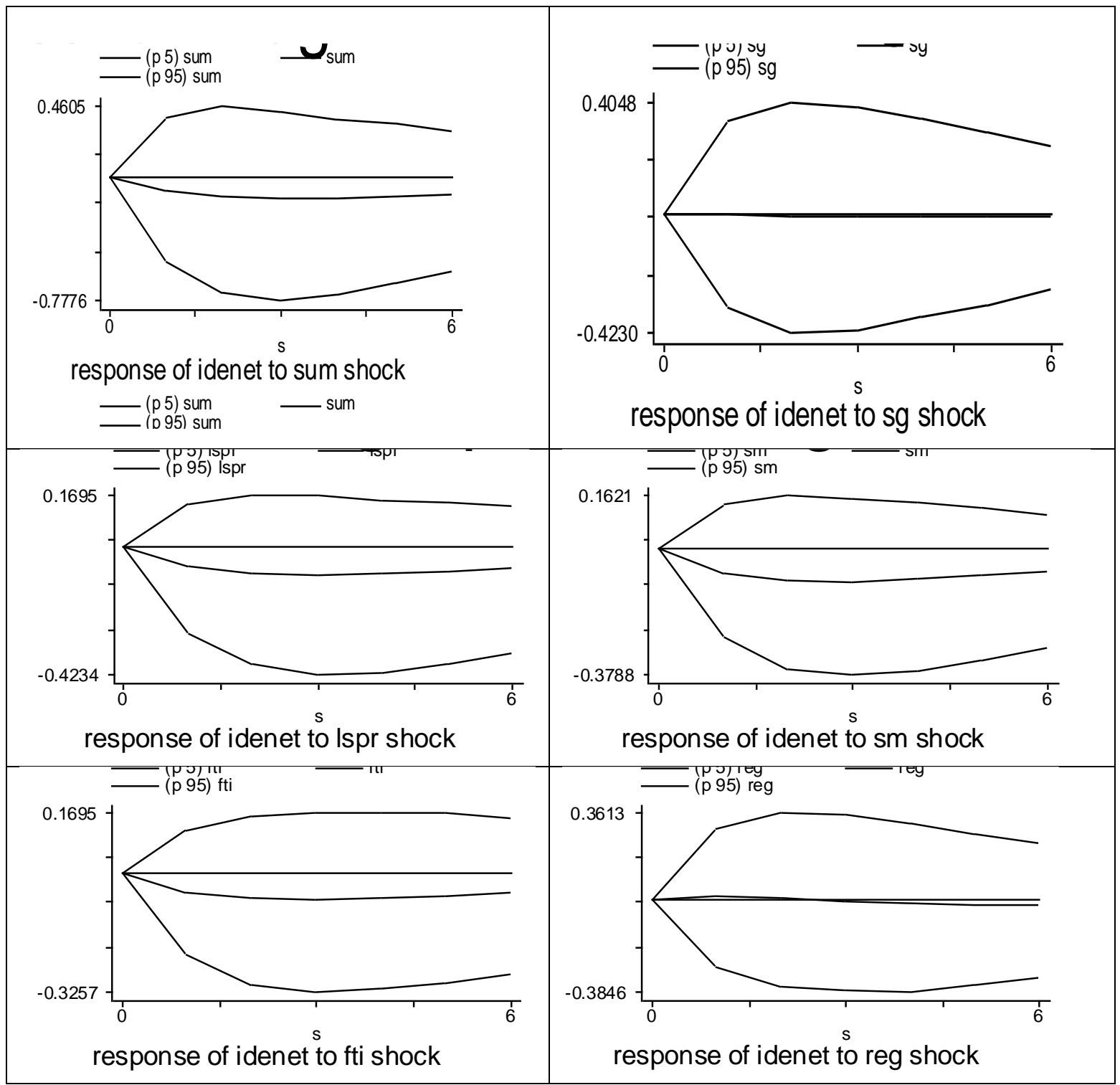

Source: author's estimates 
Table 3. Variance decomposition of the PVAR model (Institutions and net FDI)

\begin{tabular}{|l|l|l|l|l|l|l|l|}
\hline & S & idenet & Sg & Lspr & Sm & Fti & reg \\
\hline idenet & 10 & 0.9912 & 0.00001 & $\mathbf{0 . 0 0 3 3}$ & $\mathbf{0 . 0 0 3 3}$ & 0.0017 & 0.0002 \\
\hline Sg & 10 & 0.0162 & 0.9694 & 0.0047 & 0.0055 & 0.0004 & 0.0035 \\
\hline Lspr & 10 & 0.0064 & 0.0006 & 0.9749 & 0.0036 & 0.0024 & 0.0118 \\
\hline Sm & 10 & 0.0008 & 0.0014 & 0.0378 & 0.8565 & 0.0499 & 0.0533 \\
\hline Fti & 10 & 0.0004 & 0.0120 & 0.0579 & 0.0190 & 0.9054 & 0.0050 \\
\hline Reg & 10 & 0.0089 & 0.0004 & 0.0545 & 0.0156 & 0.0098 & 0.9106 \\
\hline idenet & 20 & 0.9901 & 0.00001 & 0.0038 & 0.0036 & 0.0019 & 0.0004 \\
\hline Sg & 20 & 0.0162 & 0.9642 & 0.0066 & 0.0071 & 0.0008 & 0.0049 \\
\hline Lspr & 20 & 0.0063 & 0.0006 & 0.9706 & 0.0048 & 0.0025 & 0.0148 \\
\hline Sm & 20 & 0.0008 & 0.0014 & 0.0482 & 0.8269 & 0.0581 & 0.0644 \\
\hline Fti & 20 & 0.0005 & 0.0128 & 0.0625 & 0.0198 & 0.8976 & 0.0065 \\
\hline Reg & 20 & 0.0089 & 0.0005 & 0.0570 & 0.0166 & 0.0103 & 0.9064 \\
\hline
\end{tabular}

Source : author's estimates

The effects of institutional innovations on net FDI are shown in Figure 3. We notice that institutional shocks in developing countries have a negative impact on net FDI. Generally, the impact is stable over time or decreases slightly after the 4th year. The expansion of confidence bands throughout the first four years shows the rapid increase in uncertainty during this period. It keeps narrowing down more and more.

The net FDI variance decomposition table clearly shows that this shock is mainly explained by the instabilities of the variables "Lspr" and "sm".

\section{Conclusion}

This paper attempted to study empirically the effect of institutionnel shocks on FDI in developing economies.

Using panel data for 90 developing countries from 2000 to 2016, by employing panel vector autoregression model (PVAR), we contribute to the literature by analyzing the impact of institutional shocks on three FDI variables (FDI inflows, FDI outflows end net FDI), by using various institutional measures including a composite institutional indicator.

The results showed that FDI inflows and outflows can be negatively influenced by institutional shocks. For FDI inflows, the instability of the two variables "Regulation of credit, labor and business" and "government size " contributes in reducing it by $0.81 \%$ and $12.43 \%$ respectively. For FDI outflows, instability of these same variables « Regulation of credit, labor and business " and "government size " participates in lowering it by $0.64 \%$ and $12.24 \%$ respectively. We have to note that this higher institutional effect in the case of FDI inflows can be explained by the low sensitivity of investors already settled in developing countries to institutional shocks. Two other institutional variables were found to be able to influence net FDI, which are "Ispr" an "sm" with very low effects, from the variance decomposition table.

This negative effect of institutional shocks which generally begins to diminish after the fourth year confirms the remarks of D. North (1990) considering that the restructuring of rules and 
institutions at a higher level requires a cost and the dedication of resources and that taking advantage of opportunities for institutional change depends on both the completeness of information and the mental constructs used to process that information. Thus, policymakers should put in place efficient, high-quality institutions that can stimulate investment and therefore economic growth so that they can absorb the cost of institutional change later.

\section{Appendix}

\section{A1. 90 Developing Countries}

1- Albania, 2- Algeria, 3- Angola, 4- Argentina, 5- Armenia, 6- Azerbaijan, 7- Bahamas, 8Bahrain, 9- Bangladesh, 10- Barbados, 11- Belize, 12- Benin, 13- Bolivia, 14- Bosnia and Herzegovina, 15- Botswana, 16- Brazil, 17- Burkina Faso, 18- Burundi, 19- Cameroon, 20Central Afr. Rep., 21- Chile, 22- China, 23- Colombia, 24- Congo Dem. R., 25- Congo, Rep. 26Costa Rica, 27- Cote d'Ivoire, 28- Dominican Rep., 29- Ecuador, 30- Egypt, 31- El Salvador, 32- Fiji, 33- Gabon, 34- Ghana, 35- Guatemala, 36- Guinea-Bissau, 37- Guyana, 38- Honduras, 39- Hong Kong, 40- India, 41- Indonesia, 42- Iran, 43- Jamaica, 44- Jordan, 45- Kazakhstan, 46- Kenya, 47- Korea, South, 48- Kuwait, 49- Kyrgyz Republic, 50- Lesotho, 51- Macedonia, 52- Madagascar, 53- Malawi, 54- Malaysia, 55- Mauritania, 56- Mauritius, 57- Mexico, 58Moldova, 59- Mongolia, 60- Morocco, 61- Mozambique, 62- Namibia, 63- Nicaragua, 64- Niger, 65- Nigeria, 66- Oman, 67- Pakistan, 68- Panama, 69- Pap. New Guinea, 70- Paraguay, $71-$ Peru, 72- Philippines, 73- Rwanda, 74- Senegal, 75- Serbia, 76- Sierra Leone, 77- Singapore, 78- Sri Lanka, 79- Syria, 80- Thailand, 81- Togo, 82- Trinidad \& Tob., 83- Tunisia, 84- Turkey, 85- Uganda, 86- Unit. Arab Em., 86- Uruguay, 87- Venezuela, 89- Zambia, 90- Zimbabwe.

\section{A2. Definitions of Institutional Factors}

- Size of Government - As government spending, taxation, and the size of governmentcontrolled enterprises increase, government decision-making is substituted for individual choice and economic freedom is reduced.

- Legal System and Property Rights - Protection of persons and their rightfully acquired property is a central element of both economic freedom and civil society. Indeed, it is the most important function of government.

- Sound Money - Inflation erodes the value of rightfully earned wages and savings. Sound money is thus essential to protect property rights. When inflation is not only high but also volatile, it becomes difficult for individuals to plan for the future and thus use economic freedom effectively.

- Freedom to Trade Internationally - Freedom to exchange-in its broadest sense, buying, selling, making contracts, and so on-is essential to economic freedom, which is reduced when freedom to exchange does not include businesses and individuals in other nations.

- Regulation - Governments not only use a number of tools to limit the right to exchange internationally, they may also develop onerous regulations that limit the right to exchange, gain credit, hire or work for whom you wish, or freely operate your business. 


\section{References}

- Abrigo, M and Love, I (2016) Estimation of Panel Vector Autoregression in Stata, Stata Journal 16(3):778-804. https://doi.org/10.1177/1536867X1601600314

- Ahlquist, John S. (2006) Economic policy, institutions, and capital flows: portfolio and direct investment flows in developing countries. International Studies Quarterly 50: 681704. https://doi.org/10.1111/j.1468-2478.2006.00420.x

- Aizenman, J., \& Spiegel, M. (2006) Institutional efficiency and the investment share of foreign direct investment. Review of International Economics, 14(4), 683-697. https://doi.org/10.1111/j.1467-9396.2006.00595.x

- Asiedu, E. (2006) Foreign direct investment in Africa: The role of natural resources, market size, government policy, institutions and political instability. The World Economy, 29(1), 63-77. https://doi.org/10.1111/j.1467-9701.2006.00758.x

- Alemu, A.M. (2012) Effects of Corruption on FDI Inflow in Asian Economies, Seoul Journal of Economics, 25 (4), pp. 387-412.

- Amal, M Thigo, T. B. and Raboch, H (2010) Determinants of foreign direct investment in Latin America. Revista Journal, 4 (3), pp 116- 133

- Azam, M., \& Khattak, N. (2009) Social and political factors effects on foreign direct investment in Pakistan. Gomal University Journal of Research, 25(1), pp. 46-50.

- Bailey, N. (2017) Exploring the relationship between institutional factors and FDI attractiveness: $\quad A$ meta-analytic review, International Business Review. https://doi.org/10.1016/j.ibusrev.2017.05.012

- Bellos, S. and Subasat, T. (2012) Corruption and foreign direct investment : A panel gravity model approach. Bulletin of Economic Research, 64 (4), pp 565- 574. https://doi.org/10.1111/j.1467-8586.2010.00370.x

- Brada, J.C., Drabek, Z., Perez, M.F. (2012) The Effect of Home-country and Hostcountry Corruption on Foreign Direct Investment, Review of Development Economics, 16 (4), pp. 640-663.

- Buchanan, B.G. et al. (2012) Foreign direct investment and institutional quality : some empirical evidence. International Review of Financial Analysis 21, pp 81-89. https://doi.org/10.1016/j.irfa.2011.10.001

- Buckley, P.J. and Casson, M.C. (1976) The Future of the Multinational Enterprise, Homes \& Meier: London. https://doi.org/10.1007/978-1-349-02899-3

- Buckley, P. J., Clegg, J., \& Wang, C. (2007) Is the relationship between inward FDI and spillover effects linear? An empirical examination of the case of China. Journal of International Business Studies, 38(3), pp. 447-459. 
- Buthe, T., \& Milner, H. V. (2008) The politics of foreign direct investment into developing countries: Increasing FDI through international trade agreements? American Journal of Political Science, 52(4), pp. 741-762.

- Canova F et M Ciccarelli (2013) Panel Vector autoregressive Models a Survey, Working Paper series N¹507. https://doi.org/10.1108/S0731-9053(2013)0000031006

- Cuervo- Cazurra, A. (2006) Who Cares About Corruption? Journal of International Business Studies 37(6):807-822. https://doi.org/10.1057/palgrave.jibs.8400223

- Dunning, J.H. (1998) Location and the Multinational Enterprise: A Neglected Factor? Journal of International Business Studies, 29 (1), pp 45-66. https://doi.org/10.1057/palgrave.jibs.8490024

- Gani, A. (2007) Governance and foreign direct investment links: Evidence from panel data estimations. Applied Economics Letters, 14(10), pp. 753-756. https://doi.org/10.1080/13504850600592598

- Gani, A and Al- Abri, A.S (2013) Indicators of business environment, institutional quality and foreign direct investment: the canadian experience. Journal of international Business Studies, 30 (3), pp 513- 532.

- Gastanaga, Victor M., Jeffrey B. Nugent, and Bistra Pashamova. (1998) Host country reforms and FDI inflows: How much difference do they make? World Development, 26, pp 1299- 1314. https://doi.org/10.1016/S0305-750X(98)00049-7

- Globerman, S., \& Shapiro, D. M. (2002) Global foreign direct investment flows: The role of governance infrastructure. World Development, 30(11), pp. 1899-1919. https://doi.org/10.1016/S0305-750X(02)00110-9

- Globerman, S., \& Shapiro, D. M. (2003) Governance infrastructure and US foreign direct investment. Journal of International Business Studies, 34(1), pp. 19-39. https://doi.org/10.1057/palgrave.jibs.8400001

- Gomes Neto, D., Veiga, F. J. (2013) Financial globalization, convergence and growth : The role of foreign direct investment. Journal of International Money and Finance, 37, pp. 161-186. https://doi.org/10.1016/j.jimonfin.2013.04.005

- Grosse, R., \& Trevino, L. J. (1996) Foreign direct investment in the United States: An analysis by country of origin. Journal of International Business Studies, 27(1), pp. 139155. https://doi.org/10.1057/palgrave.jibs.8490129

- Harms, P., \& Ursprung, H. W. (2002). Do civil and political repression really boost foreign direct investments? Economic Inquiry, 40(4), 651-663. https://doi.org/10.1093/ei/40.4.651

- Hennart J.F. (1982) A theory of multinational enterprise, University of Michigan Press.

- Hsu, J., Tiao, Y.-E. (2015) Patent rights protection and foreign direct investment in Asian countries. Economic Modelling, 44, pp. https://doi.org/10.1016/j.econmod.2014.08.018 
- Hymer, S., 1976 (1960 dissertation) The International Operations of Nation Firms: A Study of Foreign Direct Investment, Cambridge, MLT Press.

- Jensen, N. M. (2003). Democratic governance and multinational corporations: Political regimes and inflows of foreign direct investment. International Organization, 57(3), pp. 587-616. https://doi.org/10.1017/S0020818303573040

- Kolstad, I., \& Villanger, E. (2008). Determinants of foreign direct investment in services. European Journal of Political Economy, 24(2), 518-533. https://doi.org/10.1016/j.ejpoleco.2007.09.001

- Kurul, Z et al. (2017) Relationship between institutional factors and FDI flows in developing countries : new evidence from dynamic panel estimation. Economies.

- Levis, M. (1979). Does political instability in developing countries affect foreign investment flow? An empirical examination. Management International Review, 19, 5968.

- Li, Q., \& Resnick, A. (2003). Reversal of fortunes: Democratic institutions and foreign direct investment inflows to developing countries. International Organization, 57(1), pp. 175- 211. https://doi.org/10.1017/S0020818303571077

- Loree, D. W., \& Guisinger, S. E. (1995) Policy and non-policy determinants of us equity foreign direct-investment. Journal of International Business Studies, 26(2), pp. 281-299. https://doi.org/10.1057/palgrave.jibs.8490174

- Love, I and Zicchino, L. (2006) Financial Development and Dynamic Investment Behavior: Evidence From Panel Vector Autoregression. The Quarterly Review of Economics and Finance, 2006, vol. 46, issue 2, 190-210. https://doi.org/10.1016/j.qref.2005.11.007

- Mahmood, N. et al (2018) Foreign direct investment and institutional stability: who drives whom? www.emeraldinsight.com/2077-1886.htm

- Quazi R. M. (2014) Corruption and Foreign Direct Investment in East Asia and South Asia: An Econometric Study, International Journal of Economics and Financial Issues, 4 (2), pp. 231-242.

- Root, F. R., \& Ahmed, A. A. (1979) Empirical Determinants of Manufacturing Direct Foreign Investment in Developing Countries. Economic Development and Cultural Change, vol. 27, issue 4, 751-67. https://doi.org/10.1086/451139

- Samimi, A.J., Monfared, M. (2011) Corruption and FDI in OIC Countries, Information Management and Business Review, 2 (3), pp.106-111. https://doi.org/10.22610/imbr.v2i3.888

- S'anchez-Mart'ın Miguel Eduardo et al. (2014) Do changes in the rules of the game affect FDI flows in Latin America ? A look at the macroeconomic, institutional and regional integration determinants of FDI. https://doi.org/10.1016/j.ejpoleco.2014.02.001 
- Sethi, D., Guisinger, S. E., Phelan, S. E., \& Berg, D. M. (2003) Trends in foreign direct investment flows: A theoretical and empirical analysis. Journal of International Business Studies, 34(4), pp. 315-326. https://doi.org/10.1057/palgrave.jibs.8400034

- Stevens, G. V. G. (1969). U.S. direct manufacturing investment to Latin America: Some economic and political determinants. AID Research Paper.

- Trevino, L. J., Thomas, D. E., \& Cullen, J. (2008) The three pillars of institutional theory and FDI in Latin America: An institutionalization process. International Business Review, 17(1), pp. 118-133. https://doi.org/10.1016/j.ibusrev.2007.10.002

- Wei, S. J. (2000a) How taxing is corruption on international investors? Review of Economics and Statistics, 82(1), pp. 1-11. https://doi.org/10.1162/003465300558533

- Wei, S. J. (2000b) Local corruption and global capital flows. Brookings Papers on Economic Activity, 2, pp. 303-354. https://doi.org/10.1353/eca.2000.0021

- Wheeler, D., \& Mody, A. (1992) International investment location decisions: The case of US firms. Journal of International Economics, 33(1), pp. 57-76. https://doi.org/10.1016/0022-1996(92)90050-T

- Woo, J.Y (2010) « The impact of corruption on a country's FDI attractiveness : a panel data analysis, 1984- 2004 ». Journal of international and area studies, 17 (2), pp. 71-91.

- Woodward, D. P., \& Rolfe, R. J. (1993). The location of export-oriented foreign direct investment in the Caribbean Basin. Journal of International Business Studies, 24(1), pp. 121-144. https://doi.org/10.1057/palgrave.jibs.8490228 